\title{
THE LIFE OF HELL IN THE QUR'AN
}

\author{
Syamsul Qamar ${ }^{1}$ \\ M. Galib ${ }^{2}$ \\ Muhammadiyah $\mathrm{Amin}^{3}$ \\ Firdaus 4
}

Tarbiyah and Teaching Faculty of UIN Alauddin Makassar ${ }^{1}$

Ushuluddin, Philosophy and Politics Faculty of UIN Alauddin Makassar ${ }^{2}$

Shari'ah and Law Faculty of UIN Alauddin Makassar ${ }^{3}$

Adab and Humanities Faculty of UIN Alauddin Makassar ${ }^{4}$

syamsul.qamar@uin-alauddin.ac.id ${ }^{1}$,m.galib@uin-alauddin.ac.id ${ }^{2}$, muhammadiyah.amin@uin-alauddin.ac.id ${ }^{3}$, firdaus_uinmakassar@yahoo.com ${ }^{4}$

\begin{abstract}
This paper elaborates on the life of hell in al-Quran. This type of research is library research (library research) that is descriptive qualitative. The approaches used in this research are interpretive, theological, philosophical, and semantic approaches. Data were collected using the method of exegesis, namely, maudū'I method, both primary data in alQuran, starting from verses, clauses, phrases, to vocabulary related problem studies, as well as secondary data in the form. The decline of al-Quran is linguistic data, and data relating to the theory. The collected data were interpreted with textual, linguistic, systemic, and socio-historical interpretations. The results of the research show that the life of hereafter becomes a belief of every human being that there is life after this world life which is symbolized by the life of heaven and life of hell. The inhabitant life of hell is depicted in terms of neither living nor dying. This is because their lives are filled with bad things they do while living in this world and have a bad result in the form of death.
\end{abstract}

\section{Keywords: Life of Hell}

\section{INTRODUCTION}

One of the problems that became the main issue in the Prophet's da'wah in the Makiyyah period and the theme of the revelation of al-Quran is about the existence of an afterlife after world life. The issues surrounding this ukhrawi problem in the language of academic philosophy are called eschatology. ${ }^{1}$ Eschatology is the doctrine of the end, a doctrine that deals with beliefs related to the final events of human life such as death, doomsday, ending of the world, resurrection, the final judgment, heaven, and hell. ${ }^{2}$

Fazlur Rahman views the issue of eschatology as very urgent, because in AlQuran this idea occupies a central and significant position, besides the idea of God. ${ }^{3}$ Rahman put this eschatology as one of the major themes of al-Quran. Rahman views,

${ }^{1}$ The term eschatology comes from the Greek word, "eschatos ", which means: last; next; or the farthest. This term was adopted from Christian theology to refer to the final doctrine. See Peter A. Angeles, Dictionary of Philosophy (New York: Harper \& Row Publisher, 1981), h. 80; Absar Ahmad, “Time and Eschatology", Islamic Studies, XXXIX (Spring 2000), 82; Gabriel Fackre, "Eschatology and Systematics", Ex Auditu, VI (1990), 102.

${ }^{2}$ Peter A. Angeles, Dictionary of Philosophy, h. 80.

${ }^{3}$ Fazlur Rahman, Major Themes of the Qur'an (Chicago \& Minneapolis: Bibliotheca Islamica, 1980), h. 117-118. 
"In terms of al-Quran, no real morality is possible (created) without regulative ideas about God and the Final Judgment". ${ }^{4}$ In other words, any doctrine that the verses of alQuran give rise to cannot be separated from its connection with the doctrine of the end of the question of eschatology.

In Islam, the issue of eschatology is simply classified into two parts, namely the end of the world and the hereafter. ${ }^{5}$ The context of the world end, the discussion of Islamic eschatology is focused on the concept of the world end. However, before this apocalypse, there were also known Islamic eschatological figures, namely Ya'jüj dan Ma'jūj, Imam Mahdi, Dajjāl, and Isā as. Meanwhile, in the context of the hereafter, the discussion is focused on the concept of the resurrection day, the concept of court, and the concept of heaven and hell. In the discussion of the hereafter, most of the commentators also mention in detail the belief in Barzakh between death, resurrection, and the final judgment. Regarding the concept of death, there are indications in alQuran that the experience of human existence consists of two deaths and two lives. The first death is the period before humans are born, while the second death is the death of humans after being born. The first life is life in the world, while the second life is the hereafter. The first death, because it seems mythological, and not a series of life, is not included in the eschatological field; his field began with his second death.

Hereafter life into every human belief that there is life after this life, moreover, muslims are to pursue the happiness of the world and the hereafter. This dual-purpose is symbolized in a very popular prayer and is read daily, taken from a series of words of Allah in QS al-Baqarah/2:201;

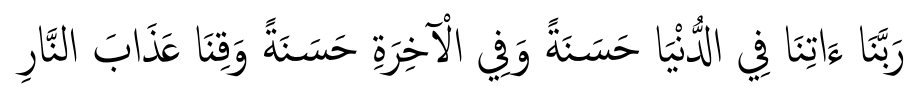

Translation:

"O Allah, give us goodness in this world and goodness in the hereafter and protect us from the torments of hell. ${ }^{\prime 6}$

The above verse explicitly teaches humans to pray that they will be given a good life, in this world and in the hereafter which is symbolized by heaven and take refuge to be kept away from the torments of hell which is an indication of a life that is miserable or not good.

According to al-Maraghi, to achieve a good life in the world one must follow the causes that have been proven by the experience of its benefits in terms of trying and regulating the order of life, interacting with the community, decorating oneself with noble morals, and upholding religious law and holding on to recognized virtues in

${ }^{4}$ Fazlur Rahman, Major Themes of The Qur'an... h. 117-118.

${ }^{5}$ William J. Hamblin \& Daniel C. Peterson, "Eschatology", The Oxford Encyclopedia of the Modern Islamic World, edited by John L. Esposito, et.al. (New York \& Oxford: Oxford University Press, 1995), h. 440. Compare with Owen, "Eschatology", 48; Glasse, who views two eschatological things, namely the End Times before the end and the life of the last days. See Cyril Glasse, The Concise Encyclopedia of Islam (London: Stacey International, 1989), h. 107. In Islam, graphic painting of human existence, as long as it is a standard understanding among scholars, is depicted with a continuum, not a circle, as is the case in Hinduism, which makes room for the concept of reincarnation. See the full discussion of Hinduism between the Encyclopedia of Religion, diedit oleh Vergilius Ferm (Connecticut: Greenwood Press, 1976), h. 337-339.

${ }^{6}$ Kementerian Agama RI., Al-Qur'an dan Terjemahnya (Madinah: Mujamma' al-Malik Fahd li Thiba' at al-Mushaf as-Syarif, 1415 H.), h. 49. 
social life. Meanwhile, to achieve a good life in the hereafter is through sincere faith, doing good deeds, and adorning oneself with noble morals and virtues ${ }^{7}$

When contrary to the good ways of life, then a bad life becomes the implication. The bad life is symbolized by the life of hell. Al-Quran has much to say about the state of life in hell. This paper elaborates on the life of hell in al-Quran.

\section{RESEARCH METHOD}

This paper elaborates on the life of hell in al-Quran. This type of research is library research (library research) that is descriptive qualitative. The approaches used in this research are interpretive, theological, philosophical, and semantic approaches. Data were collected using the method of exegesis, namely, maudu' $I$ method, both primary data in al-Quran, starting from verses, clauses, phrases, to vocabulary related problem studies, as well as secondary data in the form. The decline of al-Quran is linguistic data, and data relating to the theory. The collected data were interpreted with textual, linguistic, systemic, and socio-historical interpretations.

\section{RESULT}

The existence of the inhabitants of hell is described by Allah as not living and not dying, they are not condemned to die, but also not alive. That is a picture of the awesomeness that the inhabitants of hell receive. Allah s wt said in QS. Tăha/20:74, that;

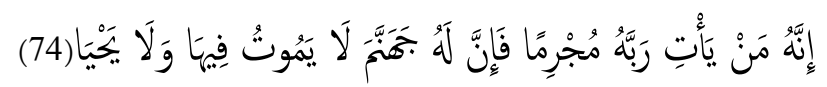

Translation:

"Indeed, whoever comes to His in a state of sin, then in truth to him hell is hell. He is not dead in it and is not (also) alive.'

Al-Marāi $\bar{i}^{9}$ interprets the above verse by saying that a person who meets Allah in a state of sin because of his disbelief and immorality will get hell. He does not die which causes his punishment to end, nor does he live well which causes him to enjoy eternal pleasures.

By quoting al-Mubrid opinion, al-Marāgi continues his interpretation, that the expert in the hell is not dead who causes rest and pleasure, nor is life capable of feeling pleasure. The person feels suffering as if the living feels it and with that suffering, he reaches a state of death in calamity, it's just that he never stops suffering. ${ }^{10}$

M. Quraish Shihab interprets the above verse by saying that people who die in disbelief and meet Allah as the perpetrator of evil, then the reward is hell. He does not die in it until he is free from torment, nor does he live until he feels pleasure.

In the Tafsir Jalālayn it is explained that (in fact whoever comes to His in a sinful state) is in a state of disbelief, then actually for him is hell. He does not die in it

\footnotetext{
${ }^{7}$ Ahmad Mustafa al-Maraghi, Tafsir al-Maraghi, Juz I (Beirut: Dar al-Fikr, 1979), h. 245.

${ }^{8}$ Departemen Agama RI., Al-Qur'an dan Terjemahnya, (Madinah: Mujamma' al-Malik Fahd li al-Ṭibā'ah al-Muṣhaf al-Syarif, 1439 H.), h. 484.

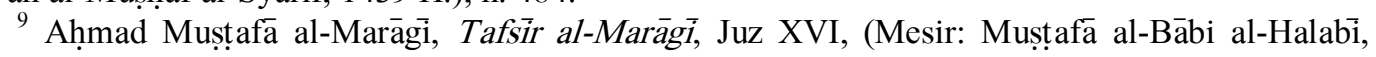
1974), h. 227.

${ }^{10}$ Al-Marāgi, Tafsìr al-Marāgī, Juz XVI, h. 227,
} 
so that he can rest from the pain of punishment (and neither does he live) with a life that is worthy and beneficial to him.

Then His word in QS. Fạtir/35:36, that;

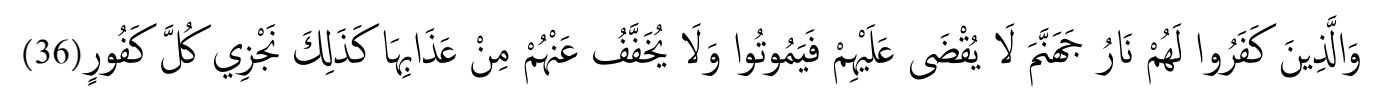

Translation:

"And those who disbelieve for them (Jahannam). They are not destroyed so that they die and not (also) are relieved of their punishment. Thus we repay everyone who is very disbelieving. ", 1

In Tafsir Jalālayin it is explained that "And for them the disbelievers are hellbent; they are not destroyed, by being killed (so that they die) that is free from pain (and not-only-relieved from them the punishment) even for an instant. (Thus) as we give retribution to them. We reply to everyone who is very disbelieving, recitation of Najziy can also be read Yajziy, the meaning of the pronunciation Kafur is an infidel.

Whereas M. Quraish Shihab interprets the above verse by saying, "And as for the disbelievers who cover up with stubbornness and arrogance of divine truth, then for them is hell." Don't think that they will soon be freed from the torment of death due to the torment of hell. In the torment of hell, they are not destroyed at all so that causing them to die nor the passage of time will result in relieving from them the punishment of that hell. Thus, they are not for a moment missed or able to rest from the torment. Thus we repay every very disbelieving person, whether living at the time of Muhammad nor before or after that period. In their state of being serious and loudly shouting in it that is hell, saying: O God! Get us out of this, surely we will do righteous deeds that are different from what we have been doing so far. ${ }^{12}$

Their screams did not make the torment easier. They continued to be tortured and told them whether we did not extend your age insufficient time to think for people who would think and when that time you should have welcomed the guidance of the prophet and did good deeds, and did not come to you a warning with the arrival of the apostles, scripture and its heirs? Then feel our punishment because it also does not exist foryou who are wrongdoers and all who do wrong are also helpers. $^{13}$

The point is for unbelievers, the reward they were promised was the hell that they would enter. At that time, Allah did not destroy them again so that they would never die. Their punishment will not be lightened, so they will not get a break. Thus we reply to everyone who is outrageous and continues to defend kufr.

Likewise in QS. al-A'lā/87:12-13 Allah also said that:

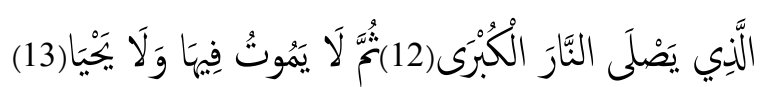

\footnotetext{
${ }^{11}$ Departemen Agama RI., Al-Qur'an dan Terjemahnya, h. 710.

${ }^{12}$ M. Quraish Shihab, Tafsir Al-Misbah: Pesan, Kesan dan Keserasian Al-Qur'an, Vol. 11(Cet. II; Jakarta: Lentera Hati, 2002), h. 480

${ }^{13}$ M. Quraish Shihab, Tafsir Al-Misbah: Pesan, Kesan dan Keserasian Al-Qur'an, Vol. 11, h. 480.
} 
Translation:

"(Namely) one who will enter into the great fire (hell). Then he does not die in it nor does he live."14

M. Quraish Shihab ${ }^{15}$ interpret the above verse by saying that said يَصْلَى taken from the word sala صَّ which is understood by some linguists to mean "to light a fire to get warm (heat)". In this verse it is interpreted as "burning", "feeling the heat of the fire" and there are also those who understand it as "entering". Al-nār al-kubrāa ( النَّرَ (الْكُْْكى agreed in the sense of a very large (hell) fire (flame). It's just that, interpreters have different views on meaning الكبرى (very big), some think that it is very large compared to the fire of the world and there are also those who understand it as "the biggest flames of fire" so that it is grieved in torment compared to other levels of hell.

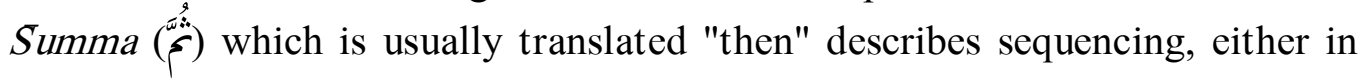
terms of ranking from bottom to top, or from top to bottom, or simply the order in the news. In this verse, the ordering is not in the rank of torment, because if so the torture mentioned by this verse exceeds the rank of al-nār al-kubrā, even though the above verse does not inform a torment, but describes the condition of those being tortured. ${ }_{-}^{16}$

Next, لَالَيُوتُ فِيهَ وَلَالَ يَحَيْا whose literal translation is, "He did not die in it (hell) nor did he live" illustrates how the person concerned experienced a very painful torment and could not escape it. In this worldly life, one can avoid torment through two causes. First, the torment is lifted so that the tormented person no longer experiences it and thus can live in peace; Second, the one who was tormented died. Verse 13 illustrates that the tormented person in the hell does not live in peace because he continues to feel the torment, nor does he die so that he can avoid the torment. ${ }^{17}$

In Tafsir Jalālayn, verse 13 is interpreted as saying that he cannot die so that he stops from his torment, nor does he live with a life that benefits him. Even his life is suffering and harm to him because with his eternal life he always suffers the pain of torment and various kinds of retribution inflicted upon him eternally. Muhammad said:

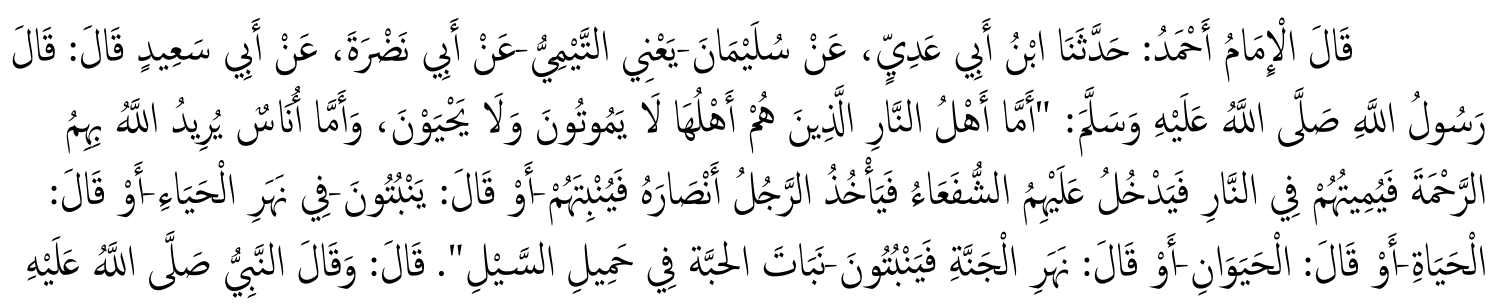

\footnotetext{
${ }^{14}$ Departemen Agama RI., Al-Qur'an dan Terjemahnya, h. 1052.

${ }^{15}$ M. Quraish Shihab, Tafsir Al-quran al-Karim: Tafsir atas Surah-Surah Pendek Berdasarkan Urutan Turunnya Wahyu(Cet. I; Bandung: Pustaka Hidayah, 1997), h, 429-430.

${ }^{16}$ M. Quraish Shihab, Tafsir Al-Quran al-Karim: Tafsir on Surah-Surah Pendek Berdasarkan Urutan Turunnya Wahyu, h, 429-430.

${ }^{17}$ M. Quraish Shihab, Tafsir Al-Qur'an al-Karim: Tafsir on Surah-Surah Pendek Berdasarkan Urutan Turunnya Wahyu, h, 429-430.
} 


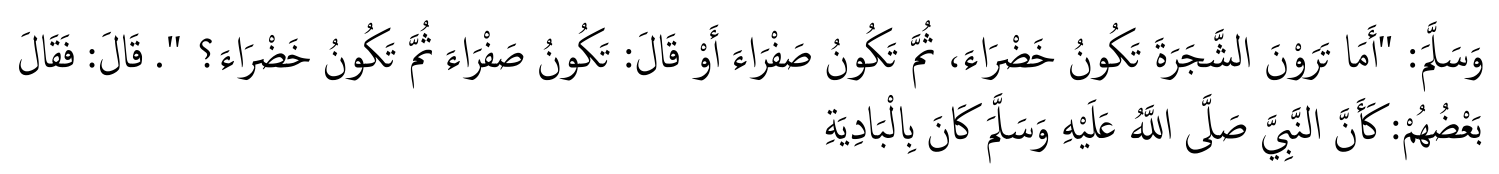

Meaning:

"Imam Ahmad said that he had told us Ibn Abu 'Adiy from Sulaiman namely At-Tamimi from Abu Nadrah from Abu Sa'id who had said that Rasulullah once said: As for the experts in hell who are permanent residents, they are neither dead nor alive. And those who are willed by Allah get (His) mercy, then Allah kills them in hell, and those who have been permitted to intercede come in to meet them, then someone of the intercessors takes a large group of people and he grows them. By putting them into the river of life, or into the river which is in heaven, until they grow (live) again as the grain brought by the flood grows (by the river). And the narrator continues that Rasulullah; he also said: Have you ever seen the process of growing trees, at first green, then yellow, then green again? The narrator continued, that some of them said that Muhammad narrating this as if been in rural areas."

In essence, the life of the inhabitants of hell is depicted in terms of neither living nor dying. This is because their lives are filled with torments due to the bad things they do while living in this world and that torture has a bad result in the form of death.

\section{IV.CLOSING}

Based on the description above, it can be concluded that the hereafter life becomes every human belief that there is life after this life on heaven and hell life. The life of the inhabitants of hell is depicted in terms of neither living nor dying. This is because their lives are filled with torments due to the bad things they do while living in this world and that torture has a bad result in the form of death.

\section{REFERENCE}

Angeles, Peter A., Dictionary of Philosophy New York: Harper \& Row Publisher, 1981.

Ahmad, Absar, “Time and Eschatology”, Islamic Studies, XXXIX Spring 2000.

Fackre, Gabriel, "Eschatology and Systematics”, EX Auditu, VI 1990.

Rahman, Fazlur, Major Themes of the Qur'an Chicago \& Minneapolis: Bibliotheca Islamica, 1980.

Hamblin, William J. \& Daniel C. Peterson, "Eschatology", The Oxford Encyclopedia of the Modern Islamic World, diedit oleh John L. Esposito, et.al. (New York \& Oxford: Oxford University Press, 1995.

Glasse, Cyril, The Concise Encyclopedia of Islam London: Stacey International, 1989.

Vergilius Ferm, Encyclopedia of Religion, Connecticut: Greenwood Press, 1976. 
Kementerian Agama RI., Al-Qur'an dan Terjemahnya Madinah: Mujamma' al-Malik Fahd li Thiba'at al-Mushaf as-Syarif, $1415 \mathrm{H}$.

Maraghi, Ahmad Mustafa al-, Tafsir al-Maraghi, Juz I, Bairut: Dar al-Fikr, 1979.

Shihab, M. Quraish, Tafsir Al-Misbah: Pesan, Kesan dan Keserasian Al-Qur'an, Vol. 11Cet. II; Jakarta: Lentera Hati, 2002.

Tafsir Al-Qur'an al-Karim: Tafsir atas Surah-Surah Pendek Berdasarkan Urutan Turunnya Wahyu Cet. I; Bandung: Pustaka Hidayah, 1997. 